\title{
Impact of three dimensional tomosynthesis on the detection and diagnosis of breast lesions
}

\author{
Sahar Mansour, Lamia Adel, Omina Mokhtar, Omar Sherif Omar \\ From International Cancer Imaging Society (ICIS) 14th Annual Teaching Course \\ Heidelberg, Germany. 9-11 October 2014
}

\section{Objective}

To evaluate the impact of adding 3D Tomosynthesis to Full Field Digital Mammography (FFDM) in the detection and diagnosis of breast lesions.

\section{Subjects and methods}

The study included 166 mammograms with indeterminate findings selected from 1600 mammograms. They were classified into two groups: group 1 'Diagnostic mammograms' of symptomatic women and group 2 'Screening mammograms'. Dense breasts assigned as ACR3 and ACR4 presented 69\% $(n=114 / 166)$ of the studied cases. FFDM and 3D tomosynthesis examination was done and imaging findings were evaluated before and after the use of 3D tomosynthesis images.

\section{Results}

Both modalities were compared regarding detection and diagnosis, each individually assessed, using the Pearson Chi Square tests. Detection ( $P$ value: 0.006$)$ and diagnosis $(P$ value: 0.048$)$ of breast lesions dramatically improved when 3D tomosynthesis images were considered in the evaluation. The sensitivity, specificity, and accuracy of digital mammography was $60 \%, 20.7 \%$ and $48 \%$ have significantly enhanced on applying tomosynthesis to be $94.5 \%, 74 \%$ and $89.7 \%$.

\section{Conclusion}

Three-dimensional tomosynthesis significantly enhanced the detection and characterization of breast lesions on digital mammography especially in the context of dense breast parenchyma (ACR 3\&4).
Published: 9 October 2014

doi:10.1186/1470-7330-14-S1-P11

Cite this article as: Mansour et al.: Impact of three dimensional

tomosynthesis on the detection and diagnosis of breast lesions. Cancer Imaging 2014 14(Suppl 1):P11.
Submit your next manuscript to BioMed Central and take full advantage of:

- Convenient online submission

- Thorough peer review

- No space constraints or color figure charges

- Immediate publication on acceptance

- Inclusion in PubMed, CAS, Scopus and Google Scholar

- Research which is freely available for redistribution
C Biomed Central

\footnotetext{
* Correspondence: lamiaadel73@yahoo.com
} 